\title{
The Application of Quantum Teaching Learning Model on Derivative Function using Maple Software in Informatics Engineering of South Aceh Polytechnic
}

\author{
Sera Delta Tanjung ${ }^{\mathrm{a}, 1, *}$, Ihsan $^{\mathrm{a}, 2}$ \\ ${ }^{a}$ Polytechnic of South Aceh, Merdeka Street, Coastel Reclamation Complex,Tapaktuan, 23751, Indonesia \\ ${ }^{1}$ sera.aneukmatematika92@gmail.com; ${ }^{2}$ Ihsan@poltas.ac.id
}

\section{ARTICLE INFO}

Article history:

Accepted

Keywords:

Quantum Teaching

Maple Software

Derivative Function

Students' Results

Students' Responses

\section{ABSTRACT}

In the curriculum informatics engineering program of South Aceh Polytechnic, function derivative is taught in the second semester. The derivative function is a mathematics concept who does manipulation toward a function, thus the function slope can be obtained quantity on the slanted point. The derivative function material is one of the difficult material faced by the students. Accordingly, the implementation of a learning model is a good thing to create students' interest on the subject. The media also use to support teaching and learning process as software maple. The purpose of this research is to find out the students' results who have taught by quantum teaching and also maple on derivative function and the students who have taught by conventional method, and also to know the students' responses after taught by quantum teaching and software maple on derivative material. Experimental method is used in this research by designing pre-test and post-test and control groups. The population is all of the second semester informatics engineering's students at South Aceh Polytechnic where they divided into two classes. The technique in gaining data is using two tests, they are written and questionnaire test. The result of data is analyzed by T-test, and questionnaire is analyzed by calculating the average scores which have set by Likert-scale. Research found that t-score $>$ t-table that is $2.41>1,69$. This showed that, the students' score on derivative material taught by quantum teaching by adopting media maple is better than the students' score taught by conventional method at informatics engineering of South Aceh Polytechnic. As for the students' responses, gainned the average of a proposed statements is 3.52. According to the specified criterias, the researcher concludes that the students' responses toward the implementation of quantum teaching by software maple on derivative function is very positive.

Copyright @ 2019 Politeknik Aceh Selatan. All rights reserved.

\section{Introduction}

\section{A. Background}

In the informatics engineering's curriculum of South Aceh Polytechnic, the derivative function is learnt by the second semester students. The derivative function is a mathematics concept that does manipulation on a function slope which can be gained quantitatively on a slanted point. The derivative is one of the difficult material faced by the students. Thus, teaching by a suitable model and media like Quantum Teaching could grow students' interests on the material. Quantum Teaching is a model that makes students experience the problem and its solution by their own self and doing activities based on the competency. This can be found by the learning steps of Quantum Teaching that is TANDUR (Tumbuhkan, Alami, Namai, Demonstrasi, Ulangi dan 
Rayakan). Supported by the suitable media, like maple software. The lesson is not only can taught algebraically and numerically, but also can be performed visually in graph.

\section{B. Statements of the Problem}

The problems of this research are: Is the results of the students taught by quantum teaching using maple software better than the result of students taught by conventional method? And how is the students' responses after applying quantum teaching on derivative material using software maple?

\section{Objective of The Research}

The purpose of this research is to find out the result of the students taught using quantum teaching by software maple on derivative and the result of students taught by conventional method.

\section{Literature Review}

\section{A. Quantum Teaching Learning Model}

According to [1], quantum teaching is the composition of lively learning with its nuances. It also includes all the connections, interactions and differences that maximize the learning moment. It means, this learning model invites students to directly experience problems and also find solutions maximally through a learning framework and find meaningfulness which makes a classroom becomes more lively.

The main principle of quantum teaching is "bring their world to our world, and deliver our world to theirs". The main step is to recognize the world of students. This is important because this action will give opportunity to lead, guide, and facilitate students to patience and broader sciences. According to [2], the students not only gain new knowledges, but the teachers' knowledge will also be expanded by accepting all comments of students.

The syntax or stages in learning quantum teaching are Tumbuhkan, Alami, Namai, Demonstrasi, Ulangi dan Rayakan (TANDUR).

1) Tumbuhkan: Grow interest satisfically. "What Are the Benefits for Me" (AMBAK), and take advantage of the learning life.

2) Alami: Experience by creating or bringing general experiences that can be understood by all students.

3) Namai: Name it by providing keywords, concepts, models, formulas, strategies for an "input".

4) Demonstrasi: Demonstrate by providing opportunities for students to "show that they really know".

5) Ulangi: Repeat by showing ways to recall the material and emphasizing, "I know that I do know this"

6) Rayakan: Celebrate by acknowledging for the completion, participation and acquisition of skills and sciences

According to [3], learning media is a tool of delivering information and learning messages to be conveyed by sender to the target or recipient of the message (receiver). One of the media that is starting to be used frequently in mathematics is maple software. Based on its history the first concept of Maple appeared from a meeting on November 1980 at the University of Waterloo.

Maple software is a very attractive program. Presenting easy-to-understand language because of the simplicity of the command. Maple can do calculations quickly, can solve equations in mathematics, and can draw graphs of mathematical functions. In addition, maple can display an animated pictures. Therefore, mathematics learning will be easier and more interesting if it is packaged in computer-based learning through this maple program. According to [4], the mathematical communication skills of students who use maple software are also better than without using maple software. Beside it has many advantages, maple software also has disadvantages, one of them, maple is very sensitive in the use of capitalizations in the equation. 


\section{Method}

\section{A. Type and Research design}

The design in this research is pretest-posttest control group design.

\section{B. Research Procedure}

The procedure of this research is the division of groups, namely two groups consisting of the experimental class and the control class. The experimental group was given special treatment that is learning by using a model of quantum using maple and questionnaire students' responses toward learning, while the control class is treated by conventional method. The student response questionnaire consisted of 12 (twelve) statements related to learning that had been carried out, such as the interest in participating in learning with the learning methods used, the effectiveness of using maple software in learning, and so forth. From the results of rresearch, student's results and students' responses will be analyzed based on the mentioned criteria's.

\section{Data Collection techniques}

Data collection were carried out with learning test result and the students' questionnaire responses.

\section{Data Analysis Techniques}

In a learning test data result will be analyzed byt-test formula at the significant level of $5 \%$

$$
t=\frac{\overline{x_{1}}-\overline{x_{2}}}{s^{2} \sqrt{\frac{1}{n_{1}}+\frac{1}{n_{2}}}}
$$

$\mathrm{t} \quad$ : t-test statistic

$\bar{x}_{1}:$ the average score of experimental class

$\bar{x}_{2}$ : the average score of control class

$n_{1}:$ the number of experimental class students

$n_{2}:$ the number of control class students

$S \quad$ : the combined standard deviation

The hypothesis test is done by testing the right part at a significant level $a=0.05$ with the following hypothesis formulations:

$H_{0} \quad$ : Sstudent's learning result taught by quantum teaching using Maple similar as the students' learning result taught by conventional method on derivative material in Informatics Engineering of South Aceh Polytechnic.

$H_{1}$ : Sstudent's learning result taught by quantum teaching using Maple is better than the students' learning result taught by conventional method on derivative material in Informatics Engineering of South Aceh Polytechnic.

This research using the right tail test, according to (5) the applicable test criteria's are rejected $H_{0}$ if $t$-score $\geq t_{(1-a)}$ with $\mathrm{t}_{(1-a)}$ obtained from the Student- $t$ distribution list using opportunities $(1-a)$ and $d k=(n-1)$. If $t$-score $<t_{(1-a)}$, then hypothesis $H_{0}$ is accepted ".

Students' responses through questionnaire are analyzed by calculating the average score that has been made with a Likert scale model and determination of the attitude scale determined by grouping the answers into four namely SS, S, BS and TS.

To determine the average scores of students' responses, calculated by formula:

The average score $=\sum_{i=1}^{4} \frac{\left(n_{i} \cdot f_{i}\right)}{N}$ 
The description of the average students' responses are $3<$ Average Score $\leq 4=$ very positive

$2<$ Average Score $\leq 3=$ positive

$1<$ Average Score $\leq 2=$ negative

$0<$ Average Score $\leq 1=$ very negative

\section{Results and Discussion}

A. Post Test Result Experimental and Control Classes

Here are the post test data of experimental and control class.

Table 1. The result of experimental class test

\begin{tabular}{cccc}
\hline Students & $\begin{array}{c}\text { Post } \\
\text { Test } \\
\text { Value }\end{array}$ & Students & $\begin{array}{c}\text { Post } \\
\text { Test } \\
\text { Value }\end{array}$ \\
\hline 1 & 88 & 10 & 73 \\
\hline 2 & 77 & 11 & 70 \\
\hline 3 & 85 & 12 & 87 \\
\hline 4 & 80 & 13 & 77 \\
\hline 5 & 82 & 14 & 48 \\
\hline 6 & 68 & 15 & 75 \\
\hline 7 & 56 & 16 & 58 \\
\hline 8 & 60 & 17 & 68 \\
\hline 9 & 78 & 18 & 86 \\
\hline
\end{tabular}

Table 2. The result of control class test

\begin{tabular}{cccc}
\hline Students & $\begin{array}{c}\text { Post } \\
\text { Test } \\
\text { Value }\end{array}$ & Students & $\begin{array}{c}\text { Post } \\
\text { Test } \\
\text { Value }\end{array}$ \\
\hline 1 & 58 & 10 & 70 \\
\hline 2 & 78 & 11 & 85 \\
\hline 3 & 60 & 12 & 84 \\
\hline 4 & 55 & 13 & 50 \\
\hline 5 & 45 & 14 & 45 \\
\hline 6 & 79 & 15 & 55 \\
\hline 7 & 68 & 16 & 79 \\
\hline 8 & 70 & 17 & 34 \\
\hline 9 & 35 & & \\
\hline & & &
\end{tabular}

B. Data Analysis of Research Result

a. Homogeneity of Variance and Normality of Distribution of Final Test Data

From the research result, gained data as followed:

$\bar{x}_{1}=72,78 \quad S_{1}^{2}=126,18 \quad S_{1}=11,23$

$\bar{x}_{2}=63,21 \quad S_{1}^{2}=251,47 \quad S_{1}=15,85$ 
which

$\bar{x}_{1}$ : the average om experimental class

$S_{1}{ }^{2}$ : Variance of experimental class

$S_{1}:$ standard deviation of experimental class

$\bar{x}_{2}$ : the average of control class

$S_{1}{ }^{2}$ : Variance of control class

$S_{1}$ : Standard deviation of control class

Based on the average score, variance, and standard deviation, the normality of data distribution and data homogeneity can be determined. Based on the normality test formula and homogeneity of data variance, the results obtained are those data that are normally distributed and homogeneous.

\section{b. Hypothesis Testing}

Hypothesis testing using t-test at a significant level $\alpha=0.05$, with a degree of freedom 33, obtained t-score $>\mathrm{t}$-table that is $2.41>1.69$. It mean that, it can be concluded that the learning result of students taught with quantum teaching model assisted by maple software are better than the students' learning outcomes who are taught conventionally on derivation material in Informatics Engineering of South Aceh Polytechnic.

c. Students' Response

The students' response ranged between positive and very positive, while the average score of 3.52. It means that overallly very positive. Based on the results, according to predetermined criteria, it can be concluded that the students' response to the application of the quantum teaching learning model using maple software on functional derivative material is very positive.

\section{Conclusion}

Based on the research result and data analysis, here are the conclusions:

a) Students' learning result taught by quantum teaching using Maple is better than the students' learning result taught by conventional method on derivative material in Informatics Engineering of South Aceh Polytechnic.

b) The students' responses toward the implementation of Quantum Teaching model using Maple software on derivative function are very positive. 


\section{Acknowledgment}

It will be the greatest thanks to KEMENRISTEKDIKTI due to the main contribution in PDP scheme for its grant, to LL Dikti chapter XIII Banda Aceh as the facilitator. Not to mention, the writer gratitude to director, vice director 1 anda vice director 2 of South Aceh Polytechnic to their idea, suggestion and support in order to complete this work.

\section{References}

[1] Bobby Deporter.2010.Quantum Teaching (Mempraktikkan Quantum Learning di Ruang-Ruang Kelas). Bandung: Penerbit KaifaG.

[2] Rahmah Johar. dkk. 2006. Stategi Pembelajaran. Banda Aceh: Universitas Syiah Kuala.

[3] Sudarman Denim. Media Komunikasi Pendidikan. Jakarta: Bumi Aksara, 2010.

[4] Sapawardi, Lalu, and Yuwono, Timbul. 2019. Pembelajaran Kalkulus Berbantuan Software Maple: Studi Perbedaan Hasil Kerja Mahasiswa dengan Menggunakan Maple dan Tanpa Menggunakan Maple.

[5] Sudjana. 2010. Metoda Statistika. Bandung: Tarsito. 